Zeszyty Naukowe Szkoły Głównej Gospodarstwa Wiejskiego

Ekonomika i Organizacja Gospodarki Żywnościowej nr 119, 2017: 23-36

DOI 10.22630/EIOGZ.2017.119.23

Ryszard Kata

Wydział Ekonomii, Uniwersytet Rzeszowski

\title{
Korzystanie z kredytów bankowych przez małe i średnie przedsiębiorstwa w Polsce
}

\section{Wstęp}

Małym i średnim przedsiębiorstwom (MSP), nie mówiąc o mikroprzedsiębiorstwach, trudniej jest pozyskać kapitał na rozwój działalności, w porównaniu do dużych firm. Dostęp MSP do kapitału na finansowanie działalności bieżącej jest zwykle łatwiejszy, ale również w tym przypadku duże firmy mogą zazwyczaj pozyskać ten rodzaj finansowania przy niższym koszcie kapitału. W literaturze przytacza się wiele przyczyn tej sytuacji wynikających z cech małych i średnich firm [Orechwa-Maliszewska i Kopczyk 2003, PeKaO SA 2014, Bera i Prędkiewicz 2015]. Należą do nich: mała skala działalności, niski poziom zdolności akumulacyjnych, brak wystarczającego majątku na zabezpieczenie wierzytelności, ograniczenia informacyjne (niepełna informacja, asymetria informacji) na skutek prowadzenia uproszczonej księgowości i sprawozdawczości finansowej, większe ryzyko operacyjne wynikające $\mathrm{z}$ połączenia funkcji właścicielskich i zarządczych w rękach jednej osoby lub kilku osób (spółki).

Wybór źródeł finansowania potrzeb kapitałowych MSP zależy od hierarchii źródeł finansowania, o której decyduje m.in. ich dostępność, koszt kapitału oraz elastyczność wykorzystania kapitału. Dostępność źródeł finansowania w dużym stopniu uzależniona jest od fazy rozwoju przedsiębiorstwa, która warunkuje potencjał firmy oraz ocenę jej wiarygodności przez dostawcę kapitału [Sadowska 2014]. Literatura ekonomiczna [Skowronek-Mielczarek 2002, Matejun i Szymańska 2012] podaje wiele źródeł i instrumentów pozyskiwania kapitału zewnętrznego przez przedsiębiorstwo, jednak faktyczna dostępność kapitału dla firm z sektora MSP zależy od wielu czynników i jest w praktyce mocno ograniczona. W przypadku hybrydowych instrumentów finansowania zewnętrznego (łączących cechy kapitału własnego i obcego), takich jak fundusze venture 
capital, tzw. anioły biznesu czy fundusze mezzanine, możemy raczej mówić o iluzji dostępności tych źródeł finansowania [Bygrave i Hunt 2005]. Niezależnie od fazy rozwoju (cyklu życia) przedsiębiorstwa, z wyjątkiem fazy inicjacji działalności, najpopularniejszym źródłem finansowania obcego MSP są kredyty bankowe.

Warto podkreślić różnicę między dostępem do kredytu bankowego a korzystaniem z niego, co w literaturze przedmiotu nie zawsze jest jednoznacznie ujmowane. Dostęp oznacza sytuację, w której przedsiębiorstwo może pozyskać finansowanie z kredytu bankowego, gdyż spełnia warunki dotyczące zdolności kredytowej i inne warunki pozyskania kredytu określone przez kredytodawcę. Z kolei korzystanie z kredytów oznacza faktyczne sięgnięcie przez przedsiębiorstwo po kredyt bankowy na finansowanie działalności operacyjnej lub inwestycyjnej.

Podmioty, które nie mają dostępu do kredytu, należy określić jako wykluczone kredytowo. Takie wykluczenie może mieć przyczyny endogeniczne z punktu widzenia przedsiębiorstwa (brak zdolności kredytowej, brak zabezpieczenia lub niewystarczające zabezpieczenie, brak wiarygodności kredytowej wynikający z niespłacenia wcześniejszych zobowiązań itd.) lub przyczyny egzogeniczne (dyskryminacja kredytowa lub racjonowanie kredytów ze strony banków, kontraktowe, w tym cenowe, warunki kredytu itd.).

$\mathrm{Z}$ kolei podmioty, które mają dostęp do kredytów bankowych, ale z nich nie korzystają, można określić mianem pasywnych kredytowo lub samowykluczonych kredytowo [Sawicka i Tymoczko 2014, Kata i Walenia 2015]. Samowykluczenie kredytowe rozumiane jest jako rezygnacja podmiotu gospodarczego z finansowania kredytem bankowym, jak i marginalizowanie potrzeb finansowych firmy w zakresie pozyskiwania kapitału zewnętrznego. Taka sytuacja może wynikać z następujących przyczyn:

- faktycznego (obiektywnego) braku potrzeby finansowania kredytowego,

- przekonania o niedostępności kredytu bankowego,

- przekonania o tańszym koszcie kapitału własnego w porównaniu z finansowaniem zewnętrznym,

- przekonania, że kredyt nie jest potrzebny firmie,

- obawy przed zadłużeniem i kłopotami ze spłatą zobowiązania,

- braku zaufania, czy wręcz awersji do banków, obawy przed oportunistycznym zachowaniem banków,

- braku wiedzy o dostępnych kredytach, warunkach pozyskania kredytu,

- zniechęcenia do kredytów z uwagi na wcześniejsze niekorzystne doświadczenia w kredytowaniu przedsiębiorstwa [Hakało i Ratajczak 2014, PeKaO SA 2014, Kata i Walenia 2015]. 
Przedsiębiorstwa, w aspekcie dostępu do kredytów i korzystania z nich, podzielić można zatem na trzy grupy: (1) korzystające z kredytów; (2) pasywne kredytowo i (3) wykluczone kredytowo. Taki podział w praktyce nie jest jednak łatwy do zastosowania. Chodzi w szczególności o oddzielenie podmiotów wykluczonych kredytowo od pasywnych kredytowo (samowykluczonych). W rzeczywistości, pomiędzy tymi zbiorami podmiotów, istnieje bowiem część wspólna, trudna jednak do ustalenia $\mathrm{w}$ aspekcie jej liczebności, skupiająca podmioty nieubiegające się o kredyt (pasywne kredytowo), ale faktycznie także wykluczone kredytowo. O swoim wykluczeniu mogłyby się one jednak przekonać dopiero, gdyby nieskutecznie ubiegały się o kredyt.

\section{Cel i metodyka badań}

W opracowaniu dokonano analizy sektora MSP w Polsce w aspekcie korzystania z kredytów bankowych w latach 2009-2015. Poszukiwano odpowiedzi na pytanie, jak kształtował się w tym okresie odsetek MSP korzystających z kredytów bankowych, a jak kształtował się odsetek firm, które były pasywne kredytowo lub zostały wykluczone z rynku kredytowego. Ponadto określono strukturę zobowiązań kredytowych przedsiębiorstw pod względem ich rodzaju, długości zobowiązania oraz rodzaju banku, w którym pobrano kredyt. Przedstawiono także bariery, jakie napotykają MSP, sięgając po kredyt bankowy.

W badaniach wykorzystano dane statystyczne Komisji Nadzoru Finansowego (KNF) dotyczące należności kredytowych sektora bankowego w Polsce w latach 2009-2015. Sięgnięto także po dane finansowe $\mathrm{z}$ reprezentatywnej dla sektora MSP próby 2009 przedsiębiorstw, wyodrębnionych z bazy Amadeus. Amadeus jest międzynarodową bazą danych obejmujących sprawozdania finansowe, raporty i informacje dotyczące firm prywatnych i publicznych z krajów $\mathrm{UE}^{1}$. Na potrzeby opracowania z bazy Amadeus wybrano losowo 1317 firm małych i 692 firm średnich prowadzących działalność gospodarczą w Polsce. Kryterium doboru do badania była wielkość zatrudnienia w firmie w 2007 roku (dla małych firm: 10-49 pracowników, a dla średnich: 50-249 pracowników) oraz branża według sekcji PKD. W analizie wykorzystano dane $\mathrm{z}$ jednostkowych sprawozdań finansowych firm z lat 2007-2014. Na podstawie tych informacji podjęto próbę odpowiedzi na pytanie, jak duża część populacji MSP korzysta z kredytów bankowych.

Bariery w dostępie przedsiębiorstw do kredytów bankowych analizowano na podstawie wyników badań ankietowych, zrealizowanych w 2015 roku na próbie

${ }^{1}$ Zob. Bureach Van Dijk, www.brdinfo.com 
45 firm z sektora MSP na Podkarpaciu. Dobór jednostek do badań miał charakter losowo-kwotowy tak, aby zapewnić reprezentatywność próby dla MSP prowadzących działalność gospodarczą w tym regionie (siedziba firmy). Narzędziem badawczym był kwestionariusz wywiadu z prezesem zarządu, w przypadku spółek (22\% respondentów) właścicielem firmy, a w przypadku przedsiębiorstw indywidualnych z osobami fizycznymi (78\% respondentów).

$\mathrm{W}$ analizach prowadzonych na danych z bazy Amadeus oraz danych pozyskanych z badań ankietowych do sektora MSP zaliczono wyłącznie małe i średnie przedsiębiorstwa. $Z$ kolei analizy prowadzone na danych KNF uwzględniały mikroprzedsiębiorstwa niebędące jednoosobowymi przedsiębiorcami.

\section{Wyniki badań}

Kredyty bankowe są podstawowym źródłem finansowania zewnętrznego małych i średnich przedsiębiorstw w Polsce. Bez dostępu do nich, wielu przedsiębiorstwom bardzo trudno byłoby utrzymywać bieżącą płynność i wypłacalność oraz realizować inwestycje. Według PARP [2015] w 2012 roku środki własne stanowiły $65,7 \%$ źródeł finansowania nakładów inwestycyjnych w sektorze MSP, kredyty i pożyczki krajowe $16,9 \%$ a środki z zagranicy (w tym kredyty bankowe) 7,7\%.

Ze statystyk KNF (rys. 1) wynika, że sektor MSP jako całość (łącznie z mikroprzedsiębiorstwami działającymi w formie spółek) wykazywał na koniec 2015 roku zadłużenie w bankach w wysokości 186,1 mld zł, co stanowiło 56,9\%

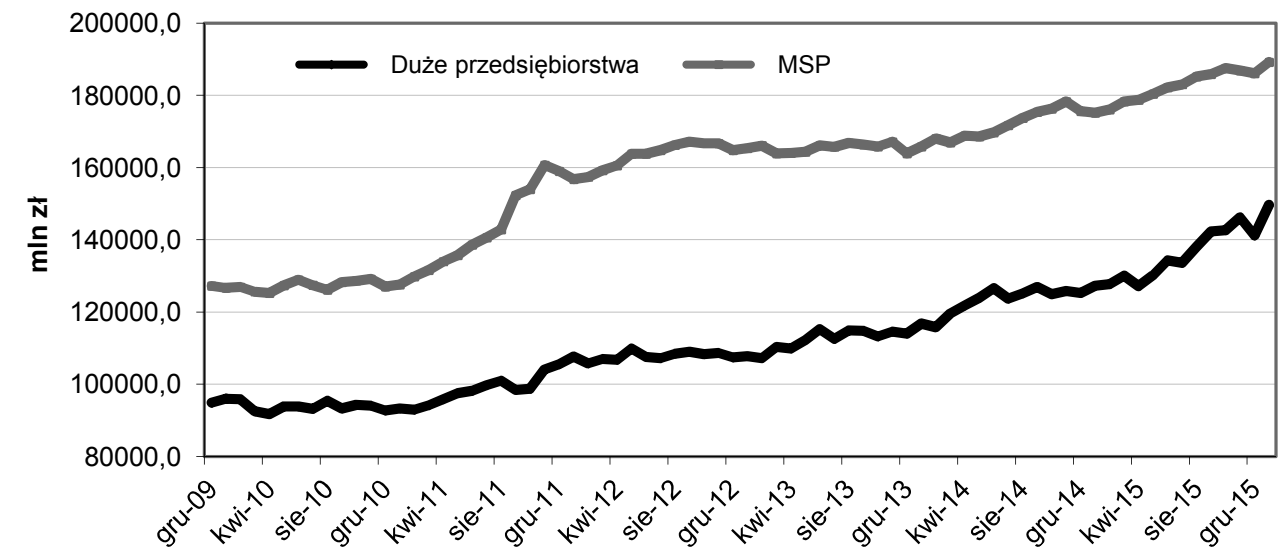

\section{Rysunek 1}

Zadłużenie przedsiębiorstw z tytułu kredytów bankowych w Polsce w latach 2009-2015

Źródło: Dane KNF, www.knf.gov.pl/dane sektora bankowego [dostęp: 26.08.2016] 
wszystkich zobowiązań przedsiębiorstw wobec banków. W 2009 roku kwota ta wynosiła 127,2 mld zł, co stanowiło wówczas 57,3\% ogółu zobowiązań kredytowych przedsiębiorstw. Między 2009 a 2015 rokiem przedsiębiorstwa z sektora MSP zwiększyły swoje zadłużenie w bankach o 46,3\% nominalnie i 31,9\% realnie. W tym samym czasie zadłużenie kredytowe dużych przedsiębiorstw w bankach zwiększyło się nominalnie o $48,8 \%$, co oznacza realny wzrost o 34,1\%. W 2015 roku znacznie szybciej rosło zadłużenie dużych przedsiębiorstw, których zobowiązania kredytowe zwiększyły się w porównaniu do końca 2014 roku o 12,7\%, a analogiczne zobowiązania MSP wzrosły o 6\%. Jak widać na rysunku 1 od końca 2011 do końca 2013 roku, obserwować można było stagnację w zakresie wielkości portfela kredytowego MSP (podobna tendencja dotyczyła także dużych przedsiębiorstw). Działo się tak mimo pojawienia się dogodnych warunków, sprzyjających zwiększeniu akcji kredytowej, m.in. obniżce stóp procentowych przez NBP. Przyczyn tego zjawiska należy upatrywać $\mathrm{w}$ niepewności związanej ze spowolnieniem rozwoju gospodarczego oraz $\mathrm{w}$ finansowaniu przez MSP projektów inwestycyjnych ze środków własnych. W latach 2014-2015 nastapił jednak wzrost zadłużenia kredytowego MSP spowodowany zapewne dalszymi obniżkami stóp procentowych oraz złagodzeniem przez banki kryteriów udzielania kredytów dla MSP (zwłaszcza krótkoterminowych), wynikającym z poprawy jakości portfela kredytowego.

W strukturze zadłużenia MSP w bankach dominują kredyty długoterminowe. Na koniec 2015 roku kredyty inwestycyjne stanowily 31,1\% zobowiązań MSP wobec banków, kredyty na zakup lub budowę nieruchomości stanowiły $23,7 \%$, z kolei udział kredytów operacyjnych wynosił $35,3 \%$, a pozostałych zobowiązań wobec banków 10\% (tab. 1). W latach 2009-2015 struktura zobowiązań MSP wobec banków była względnie stabilna, z nieznacznym wzrostem udziału kredytów inwestycyjnych a spadkiem udziału kredytów na nieruchomości oraz pozostałych zobowiązań. Najbardziej stabilny był udział kredytów operacyjnych, który w całym badanym okresie wynosił ok. 36\% (tab. 1). Łącznie kredyty

\section{Tabela 1}

Struktura zobowiązań MSP wobec banków w latach 2009-2015 [w \%]

\begin{tabular}{|l|c|c|c|c|c|c|c|}
\hline \multirow{2}{*}{ Rodzaj zobowiązania } & \multicolumn{7}{|c|}{ Stan na koniec roku [\%] } \\
\cline { 2 - 8 } & 2009 & 2010 & 2011 & 2012 & 2013 & 2014 & 2015 \\
\hline Kredyty inwestycyjne & 26,8 & 27,7 & 29,9 & 28,6 & 30,8 & 30,4 & 31,1 \\
Kredyty na finansowanie & 29,1 & 27,5 & 25,1 & 25,5 & 24,9 & 24,3 & 23,6 \\
nieruchomości & 36,2 & 36,4 & 36,2 & 37,8 & 36,0 & 35,6 & 35,3 \\
Kredyty operacyjne & 7,9 & 8,4 & 8,9 & 8,1 & 8,3 & 9,7 & 10,0 \\
Pozostałe zobowiązania & &
\end{tabular}

Źródło: Dane KNF, www.knf.gov.pl/dane sektora bankowego [dostęp: 26.08.2016]. 
o charakterze długoterminowym (inwestycyjne i na finansowanie nieruchomości) stanowiły na koniec 2015 roku 54,8\% w strukturze zadłużenia MSP w bankach. $\mathrm{W}$ przypadku dużych przedsiębiorstw struktura zadłużenia jest nieco odmienna. Znacznie większy jest udział kredytów obrotowych, który jednak zmniejszał się w badanym okresie z 51\% w 2009 roku do 40\% w 2015 roku. Wyraźnie niższy, niż w sektorze MSP, jest także udział kredytów na finansowanie nieruchomości, który w latach 2009-2015 oscylował w granicach od 6,7 do 10,9\%. Ogólnie udział kredytów długoterminowych w zadłużeniu dużych przedsiębiorstw był w latach 2009-2015 niższy w porównaniu do MSP średnio o 13,6 p.p. i na koniec 2015 roku wynosił $41,2 \%$ (rys. 2).

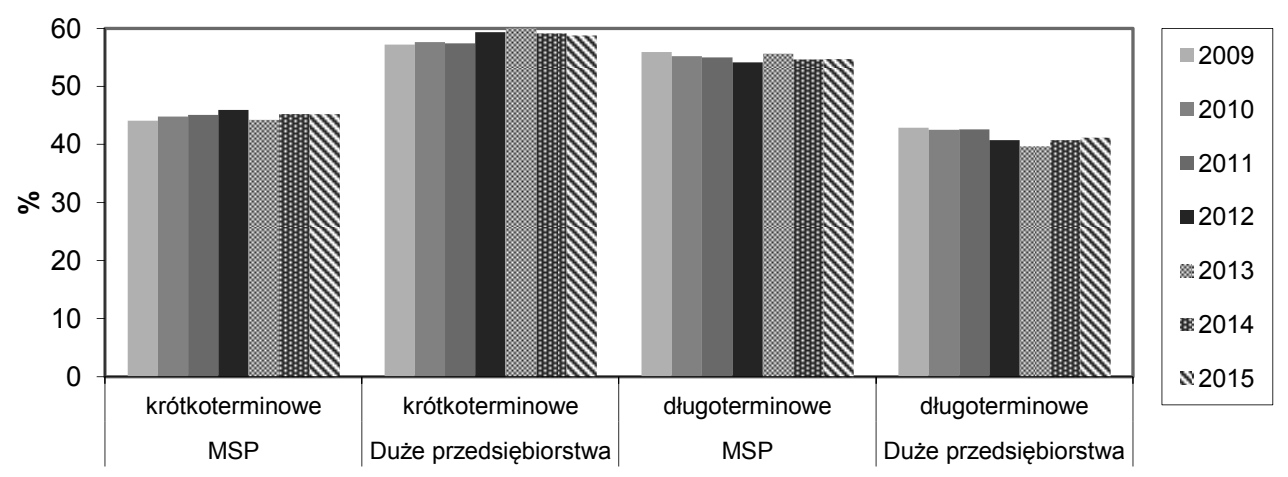

\section{Rysunek 2}

Udział kredytów krótkoterminowych i długoterminowych w strukturze zadłużenia przedsiębiorstw w bankach w latach 2009-2015

Źródło: Dane KNF, www.knf.gov.pl/dane sektora bankowego [dostęp: 26.01.2016].

Około 90\% kredytów MSP (według ich wolumenu) znajduje się w bankach komercyjnych (objętych nadzorem krajowym) lub w oddziałach instytucji kredytowych, a około $10 \% \mathrm{w}$ bankach spółdzielczych (tab. 2). Dla porównania duże przedsiębiorstwa mają zaledwie $0,3 \%$ swojego zadłużenia kredytowego w bankach spółdzielczych. Dane te wskazują, iż dla MSP lokalne banki, stanowią istotne źródło dostępu do kredytu bankowego.

Na podstawie danych pochodzących z bazy Amadeus, możemy stwierdzić, iż w latach 2007-2014 z kredytów bankowych korzystało średnio 55,9\% MSP, przy czym, z kredytów długoterminowych $33,8 \%$ MSP, a z krótkoterminowych $50,3 \%$. Około $2 / 3$ firm, finansowało kredytami zarówno przedsięwzięcia rozwojowe (inwestycje), jak i bieżącą działalność operacyjną. Między grupami MSP występują dosyć znaczne różnice w zakresie natężenia cechy, jaką jest korzystanie z kredytów bankowych. Odsetek firm korzystających z kredytów krótkoterminowych jest wyższy o ok. 15 p.p. w grupie firm średnich w stosunku do firm małych, $\mathrm{z}$ kolei w przypadku kredytów długoterminowych różnica ta 
jest jeszcze większa (tab. 3). Firmy o średniej wielkości, przeciętnie sięgały w badanym okresie po trzykrotnie wyższe kwotowo kredyty w porównaniu do małych firm. W latach 2007-2014, firmy średnie wykazywały się także przeciętnie wyższym wskaźnikiem zadłużenia $(12,2 \%)$, będącym relacją kredytów bankowych do aktywów ogółem, w porównaniu do firm małych $(10,2 \%)$. Jeśli odniesiemy jednak kwotę kredytów długoterminowych do aktywów trwałych, to okazuje się, iż w tym aspekcie firmy małe wykazują większe zadłużenie (30,2\%) w porównaniu do firm średnich (17,5\%). Ustalone dla wymienionych miar zadłużenia współczynniki zmienności znacznie przekraczają 100\% (tab. 3). Oznacza to, iż w sektorze MSP, obok dużej grupy firm, które stronią od kredytów (ok. $46 \%$ podmiotów), obserwujemy także bardzo duże zróżnicowanie poziomu zadłużenia $\mathrm{w}$ obrębie firm, które korzystają $\mathrm{z}$ kredytów. Wiele $\mathrm{z}$ nich sięga do tego źródła finansowania tylko w ostateczności, po wyczerpaniu innych możliwych do pozyskania źródeł kapitału, głównie o charakterze wewnętrznym (samofinansowanie) oraz zewnętrznym własnym (kapitały udziałowe, dotacje), co jest zgodne $\mathrm{z}$ teorią hierarchii źródeł finansowania. Inne firmy traktują kredyty bankowe jako źródło komplementarne wobec kapitału własnego, stwarzające możliwość dyskontowania pozytywnych efektów dźwigni finansowej. Średnio w latach 2007-2014 kredyty bankowe stanowiły 26,8\% w strukturze zobowiązań ogółem przedsiębiorstw, przy czym w firmach małych $25,2 \%$, a średnich $30 \%$. Udział ten wzrósł w badanym okresie o 2,8 p.p. (w firmach małych o 2,5 p.p., a w średnich o 3,5 p.p.). Oznacza to wzrost znaczenia kredytów bankowych w strukturze finansowania zewnętrznego MSP.

W latach 2007-2014 liczba podmiotów zadłużonych z tytułu kredytów bankowych ulegała nieznacznemu spadkowi. W 2014 roku firm zadłużonych w bankach było o blisko 5\% mniej niż w 2007 roku. W przypadku kredytów długoterminowych zmniejszenie się liczby zadłużonych MSP wyniosło 6,7\%

\section{Tabela 2}

Struktura zadłużenia kredytowego MSP w Polsce według banków [stan na koniec 2015 roku] [w \%]

\begin{tabular}{|l|c|c|c|}
\hline \multicolumn{1}{|c|}{ Wyszczególnienie } & $\begin{array}{c}\text { Banki } \\
\text { komercyjne }\end{array}$ & $\begin{array}{c}\text { Oddziały instytucji } \\
\text { kredytowych }\end{array}$ & $\begin{array}{c}\text { Banki } \\
\text { spółdzielcze }\end{array}$ \\
\hline Ogółem & 87,3 & 3,1 & 9,6 \\
\hline w tym kredyty: & & & 10,9 \\
\hline - operacyjne & 83,3 & 5,8 & 8,4 \\
\hline - inwestycyjne & 90,2 & 1,4 & 11,8 \\
\hline - na nieruchomości & 87,8 & 0,4 & 3,6 \\
\hline - pozostałe & 91,0 & 5,4 & \\
\hline
\end{tabular}

Źródło: Dane KNF, www.knf.gov.pl/dane sektora bankowego [dostęp: 26.08.2016]. 
(tab. 3). Znaczny wzrost notowała natomiast przeciętna kwota zadłużenia kredytowego przedsiębiorstw, co potwierdza wykazaną wcześniej, na bazie danych KNF, tendencję do dosyć dynamicznego wzrostu zadłużenia bankowego sektora MSP w Polsce. W przypadku badanych MSP (baza Amadeus) ich przeciętne zadłużenie w latach 2007-2014 niemalże podwoiło się w ujęciu nominalnym (wzrost o 94,4\%), a realnie zwiększyło się o $73,6 \%$. Z danych KNF wynika, iż ogółem zadłużenie sektora MSP wzrosło w tym okresie realnie o $36,8 \%$. Ta różnica jest zapewne efektem tego, iż dane KNF obejmują także mikroprzedsię-

\section{Tabela 3}

Charakterystyka zadłużenia kredytowego MSP w latach 2007-2014

\begin{tabular}{|l|c|c|c|c|}
\hline \multicolumn{1}{|c|}{ Wyszczególnienie } & \multirow{2}{*}{ J.m. } & \multirow{2}{*}{ Ogółem } & \multicolumn{2}{|c|}{ Firmy } \\
\cline { 4 - 5 } & & & małe & średnie \\
\hline $\begin{array}{l}\text { MSP zadłużone z tytułu kredytów bankowych: } \\
\text { - ogółem }\end{array}$ & średnia & 55,9 & 50,9 & 65,4 \\
- kr. krótkoterminowych & w \% & 50,3 & 44,7 & 60,9 \\
- kr. długoterminowych & & 33,8 & 27,3 & 46,1 \\
\hline $\begin{array}{l}\text { Przeciętne zadłużenie kredytowe: } \\
\text { a) ogółem }\end{array}$ & tys. zł & 3 363,7 & 1835,7 & 5629,5 \\
b) z tytułu kredytów krótkoterminowych & tys. zł & 1654,0 & 967,2 & 2620,9 \\
\hline $\begin{array}{l}\text { Zmiana liczby zadłużonych MSP } \\
\text { (2014/2007), 2007 = 100 }\end{array}$ & & & & \\
- ogółem & & & & \\
- z tytułu kredytów krótkoterminowych & $\%$ & 105,2 & 107,5 & 102,2 \\
- z tytułu kredytów długoterminowych & & 93,3 & 94,0 & 92,7 \\
\hline $\begin{array}{l}\text { Zmiana przeciętnej kwoty zadłużenia } \\
\text { (2014/2007), 2007=100: }\end{array}$ & & & & \\
- nominalna (wg cen bieżących) & $\%$ & 194,4 & 164,8 & 210,7 \\
- realna & $\%$ & 173,6 & 144,0 & 189,9 \\
\hline $\begin{array}{l}\text { Średnioroczna stopa wzrostu zadłużenia } \\
\text { kredytowego ogółem (wg cen bieżących) }\end{array}$ & $\%$ & 10,7 & 8,1 & 11,9 \\
\hline $\begin{array}{l}\text { Przeciętny wskaźnik zadłużenia } \\
\text { (kredyty i pożyczki/aktywa ogółem) }\end{array}$ & $\%$ & 10,9 & 10,2 & 12,1 \\
\hline - współczynnik zmienności V & $\%$ & 148,3 & 160,0 & 128,4 \\
\hline $\begin{array}{l}\text { Relacja zadłużenia z tytułu kredytów } \\
\text { długoterminowych do aktywów trwałych } \\
\text { - współczynnik zmienności V }\end{array}$ & $\%$ & 24,7 & 30,2 & 17,5 \\
\hline $\begin{array}{l}\text { Przeciętny udział kredytów w strukturze } \\
\text { zobowiązań ogółem }\end{array}$ & 201,6 & 201,6 & 159,4 \\
\hline
\end{tabular}

Źródło: Badania własne na podstawie próby 2009 firm z sektora MSP w Polsce. 
biorstwa, podczas gdy w bazie Amadeus nie ma takich firm. Wynika z tego wniosek, iż przedsiębiorstwa zatrudniające co najmniej 10 pracowników wykazują znacznie większy popyt kredytowy, niż mikroprzedsiębiorstwa. Na znaczenie wielkości przedsiębiorstwa w kontekście korzystania z kredytów wskazuje także fakt, iż znacznie szybszy wzrost zadłużenia obserwowano w firmach średnich w porównaniu do małych (tab. 3). Średnioroczna stopa wzrostu zadłużenia kredytowego w ujęciu nominalnym wynosiła $10,7 \%$ dla całej badanej zbiorowości, z kolei w grupie firm małych wynosiła 8,1\%, a firm średnich 11,9\%. Wskaźnik zadłużenia MSP (kredyty w relacji do aktywów ogółem) wzrósł jednak nieznacznie, z 10,2\% w 2007 roku do $11,0 \%$ w 2014 roku. Podobny wzrost tego wskaźnika zanotowały w badanym okresie małe firmy (z 9,7 do 10,3\%) i średnie (z 11,1 do $12,2 \%)$.

Jak wspomniano wcześniej, przedsiębiorstwa można podzielić na trzy grupy, w aspekcie korzystania przez nie z kredytów bankowych, tak jak:

1. Przedsiębiorstwa korzystające $z$ kredytów bankowych, a zatem skutecznie aplikujące o kredyt i spełniające wymogi banków, co do zdolności kredytowej. Badania MSP z bazy Amadeus wskazuja, iż w latach 2007-2014 takich firm było około $56 \%$, z kolei z badań ankietowych NBP prowadzonych w latach 2012-2013 wynika, iż było ich 53,8\% [Sawicka i Tymoczko 2014].

2. Przedsiębiorstwa aplikujące po kredyty, ale uzyskujące odmowę banku lub rezygnujące na określonym etapie $\mathrm{z}$ ubiegania się o kredyt. W przypadku tych MSP możemy mówić o wykluczeniu kredytowym. Według badań ankietowych NBP takich firm jest około 4,5\%.

3. Przedsiębiorstwa, które nie sięgają po kredyt. Te firmy z uwagi na przyczynę pasywności kredytowej możemy z kolei podzielić na:

a) podmioty podlegające samowykluczeniu kredytowemu $z$ uwagi na: (1) brak potrzeby pozyskania kredytu, gdyż mają wystarczające kapitały własne (w kontekście skali prowadzonej działalności oraz obranej ścieżki rozwoju firmy) lub pozyskały inne źródła finansowania; (2) czynniki psychoosobowe (awersja kredytowa, obawa przed bankami itp.) lub kulturowe;

b) podmioty, które wykazują zapotrzebowanie na kredyt, ale z uwagi na ograniczenia wewnętrzne (brak zabezpieczeń, niskie dochody itd.) rezygnują $\mathrm{z}$ takiego finansowania.

Podmioty, należące do ostatniej z wymienionych grup oraz podlegające samowykluczeniu kredytowemu z powodów psychoosobowych (behawioralnych) określa się w literaturze jako discouraged borrowers [Freel i in 2012]. Według tego ujęcia „zniechęcony kredytobiorca” jest dobrą w sensie ekonomicznym firmą, która potrzebuje zewnętrznego finansowania, ale z obawy o odrzucenie 
wniosku kredytowego przez bank nie decyduje się ubiegać o potrzebne środki. Zdaniem Sawickiej i Tymoczko [2014] zniechęcony kredytobiorca to taki podmiot, który nie próbuje pozyskać kredytu, bo obawia się, że albo jego koszt będzie zbyt wysoki, albo wielkość dostępnych środków będzie niewystarczająca na zaspokojenie jego potrzeb pożyczkowych. W związku z tym, przedsiębiorstwo podejmuje decyzję o samowykluczeniu z rynku kredytowego, mimo że nie istnieją ku temu żadne racjonalne przesłanki. Wielu autorów wskazuje na społecznoosobowe (w tym behawioralne), a nawet kulturowe przyczyny pasywności kredytowej [Smallbone 2003, Carter i in. 2007, Kata 2013]. Przyczyny te możemy zaliczyć do grupy ograniczeń endogenicznych. Z kolei Chakravaty i Xiang [2009] analizując zjawisko pasywności kredytowej, wskazywali na takie jej przyczyny jak: skomplikowane procedury bankowe, zbyt wysokie oprocentowanie kredytu, nadmierne w relacji do możliwości firmy wymagania w zakresie zabezpieczenia, niejasny sposób przyznawania kredytu. Te ograniczenia mają charakter egzogeniczny, ich występowanie może jednak wpływać na określone postrzeganie banków i możliwości dostępu do kredytu bankowego ze strony potencjalnego kredytobiorcy, powodując rezygnację z ubiegania się o kredyt. Ponadto Lucey i in. [2012] dowodza, że przedsiębiorstwa, które doświadczają problemów z osiąganiem zadowalających wyników finansowych, wykazują większe zapotrzebowanie na dodatkowy kapitał, ale właśnie niezadowalająca kondycja ekonomiczna jest źródłem sceptycyzmu, co do szansy uzyskania kredytu. Przedsiębiorstwa, które są niepewne własnej zdolności kredytowej (co nie jest równoznaczne z jej brakiem), rezygnują z ubiegania się o kredyt.

Przyczyny pasywności kredytowej są złożone i wzajemnie powiązane ze sobą, tzn. że niektóre ograniczenia, mając charakter pierwotny, skutkują powstawaniem kolejnych ograniczeń, decydujących ostatecznie o zaniechaniu ubiegania się o kredyt, rezygnacji z ubiegania się o kredyt już na etapie aplikacji (zniechęcenie) lub odmowie kredytu ze strony banku. Wieloaspektowość problematyki powoduje, iż analiza ograniczeń w dostępie MSP do kredytów bankowych nie może sprowadzać się do identyfikacji pojedynczej przyczyny dla konkretnego podmiotu, lecz raczej do rozpoznania „,wiązki” przyczyn składających się na pasywność kredytową lub wykluczenie kredytowe. Warto podkreślić, że zarówno pasywność kredytowa, jak i wykluczenie kredytowe mogą mieć charakter trwały lub czasowy. W tym kontekście niektóre cechy (np. psychoosobowe zarządzających) są zwykle odpowiedzialne za pasywność lub wykluczenie trwałe, inne zaś (np. sytuacja finansowa przedsiębiorstwa) są częściej powodem wykluczenia czasowego.

Na podstawie wyników badań ankietowych MSP na Podkarpaciu (2015 rok) można stwierdzić, że dostęp do kredytów bankowych jest postrzegany jako trudny lub bardzo trudny przez $61 \%$ zarządzających tego typu przedsiębiorstwami. 
Co czwarty ankietowany wskazał, iż dostęp ten jest łatwy, a pozostali (13\%), że bardzo łatwy (rys. 3). Spośród innych popularnych źródeł finansowania zewnętrznego, dostęp do kredytu bankowego jest oceniany, jako trudniejszy w porównaniu do kredytu towarowego oraz leasingu, ale za to łatwiejszy w porównaniu do franchisingu oraz dotacji z funduszy UE.

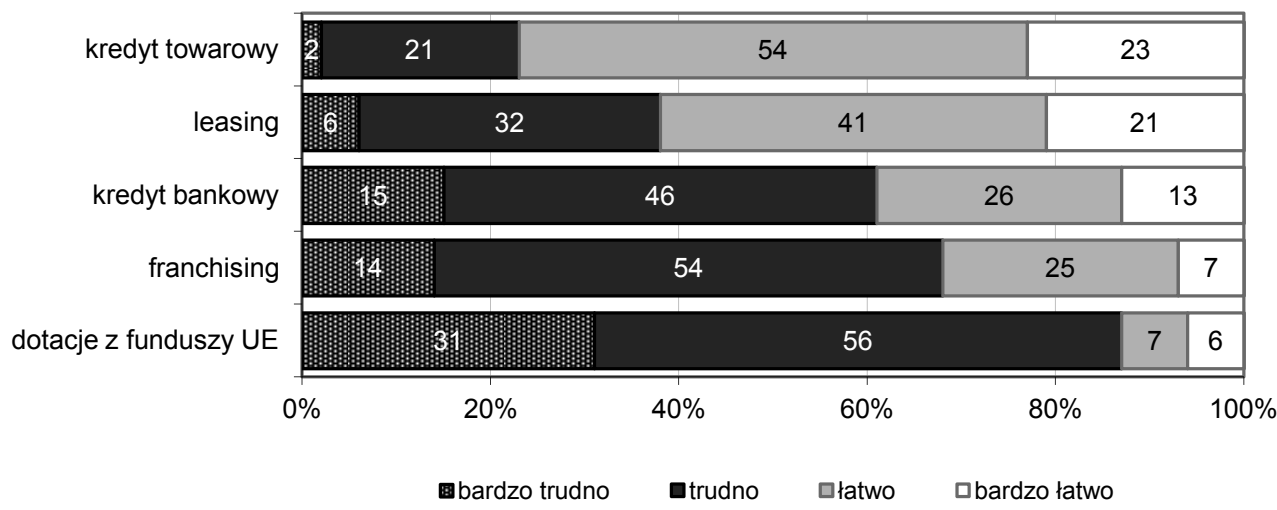

\section{Rysunek 3}

Stopień trudności pozyskania kapitału z wybranych zewnętrznych źródeł finansowania Źródło: Własne badania ankietowe (MSP z województwa podkarpackiego).

Z badań tych wynika, iż 28,9\% zarządzających MSP wskazało brak potrzeby finansowania zewnętrznego jako przyczynę niekorzystania z kredytów bankowych (tab. 4). Obok tego, najważniejszą przyczyną samowykluczenia kredytowego była niechęć do zadłużania się, wyrażona przez 13,3\% ankietowanych oraz obawa przed trudnościami ze spłatą kredytów, wskazana przez 8,9\% ankietowanych.

W opinii największej grupy przedstawicieli MSP najważniejszymi barierami w dostępie do kredytów są ich warunki cenowe (wysokie oprocentowanie, prowizje) oraz uciążliwe (skomplikowane i czasochłonne) procedury. $\mathrm{Na}$ tę ostatnią przyczynę wskazywał co piąty respondent, a ogólnie na przyczyny związane $\mathrm{z}$ warunkami kredytowania, $\mathrm{w}$ tym brakiem odpowiedniej informacji i pomocy ze strony banku, wskazywało $46,7 \%$ ankietowanych. Dla $6,7 \%$ ankietowanych przyczyną nieskorzystania z kredytu była odmowa jego udzielenia ze strony banku. Najczęściej przyczyny, które powodują czasowe lub względnie trwałe wykluczenie przedsiębiorstw z dostępu do kredytu, mające swoje źródła po stronie banków (procedury, wymogi, jakość oferty kredytowej) są największą przeszkodą dla wzrostu popytu kredytowego ze strony MSP. Z kolei, co czwarty ankietowany wskazywał na przyczyny leżące po stronie przedsiębiorstwa, przede wszystkim na niskie dochody, które warunkują zdolność kredytową oraz na brak odpowiednich zabezpieczeń dla kredytów (tab. 4). 
Tabela 4

Przyczyny niekorzystania z kredytów bankowych według wskazań ankietowanych [\%]

\begin{tabular}{|c|c|c|}
\hline $\begin{array}{l}\text { Przyczyna } \\
\text { generalna }\end{array}$ & $\begin{array}{c}\text { Przyczyna szczegółowa wg kolejności wskazań } \\
\text { respondentów }\end{array}$ & $\begin{array}{c}\text { Odsetek } \\
\text { deklarujących* }\end{array}$ \\
\hline \multirow[b]{2}{*}{$\begin{array}{l}\text { Dobrowolne } \\
\text { samowykluczenie }\end{array}$} & brak potrzeby & 28,9 \\
\hline & $\begin{array}{l}\text { kulturowe/psychoosobowe przyczyny } \\
\text { - niechęć do brania jakiegokolwiek kredytu } \\
\text { - obawa przed trudnościami w spłacie kredytu }\end{array}$ & $\begin{array}{c}13,3 \\
8,9\end{array}$ \\
\hline $\begin{array}{l}\text { Wewnętrzne } \\
\text { ograniczenia } \\
\text { ekonomiczne }\end{array}$ & $\begin{array}{l}\text { - } \text { niedostateczne dochody (niska dochodowość } \\
\text { produkcji, trudności ze zbytem produktów) } \\
\text { - } \text { brak lub niedostateczne zabezpieczenie } \\
\text { - } \\
\text { - ograniczanie działalności gospodarczej } \\
\text { - brak wkładu własnego }\end{array}$ & $\begin{array}{l}15,6 \\
4,4 \\
2,2 \\
2,2\end{array}$ \\
\hline $\begin{array}{l}\text { Wykluczenie } \\
\text { kredytowe }\end{array}$ & $\begin{array}{l}\text { - } \text { uciążliwe procedury } \\
\text { - } \text { za wysokie wymagania, co do zabezpieczeń, } \\
\text { zdolności kredytowej i inne } \\
\text { - } \text { wysokie oprocentowanie } \\
\text { - } \\
\text { - } \\
\text { - odmótki okres spłaty, brak okresu karencji } \\
\text { sku kredytowego) } \\
\text { - } \text { wysokie prowizje i inne koszty transakcyjne } \\
\text { - } \text { brak dobrej informacji i pomocy konsultingowej }\end{array}$ & $\begin{array}{l}20,0 \\
13,3 \\
11,1 \\
6,7 \\
6,7 \\
4,4 \\
2,2\end{array}$ \\
\hline
\end{tabular}

*ankietowani mogli wskazać więcej niż 1 przyczynę

Źródło: Własne badania ankietowe (MSP z województwa podkarpackiego).

\section{Podsumowanie}

Kredyty bankowe stanowią ważne źródło zewnętrznego finansowania małych i średnich przedsiębiorstw w Polsce. Przeciętnie korzysta z nich około 56\% MSP. W porównaniu do dużych firm w strukturze zadłużenia kredytowego MSP, relatywnie wyższy udział mają kredyty długoterminowe, w tym kredyty na finansowanie nieruchomości. Z kolei dynamika wzrostu zadłużenia kredytowego sektora MSP w latach 2009-2015 była podobna do dynamiki wolumenu kredytów dużych przedsiębiorstw. Firmy średnie wykazują przeciętnie trzykrotnie większe zadłużenie kredytowe niż firmy małe, co wskazuje na dodatnią zależność między wielkością firm a korzystaniem z kredytów.

Pomimo relatywnie wysokiej dostępności kredytów bankowych, wciąż duży odsetek MSP nie wykazuje zainteresowania ich pozyskiwaniem, co określa się mianem pasywności kredytowej. Jest ona pochodną zachowawczej polityki 
rozwojowej prowadzonej przez wiele MSP oraz preferowania konserwatywnej strategii finansowania przedsiębiorstwa bazującej na wewnętrznych źródłach finansowania. Problem pasywności kredytowej jest także powodowany przez czynniki behawioralne oraz sytuację ekonomiczną przedsiębiorstwa, której znamionami są: niska dochodowość działalności gospodarczej, problemy ze zbytem produktów, brak lub niedostatek zabezpieczenia kredytu, niska akumulacja funduszy własnych potrzebnych na wkład własny w realizacji przedsięwzięć inwestycyjnych.

Część przedsiębiorstw z sektora MSP podlega wykluczeniu kredytowemu ze strony banków. Ten problem ma swoje źródła w warunkach cenowo-kontraktowych kredytów, problemach natury informacyjnej oraz wciąż relatywnie skomplikowanych i czasochłonnych procedurach związanych z pozyskiwaniem kredytów.

\section{Literatura}

BERA A., PRĘDKIEWICZ K., 2015: Niektóre determinanty struktury kapitału w mikro, matych $i$ średnich przedsiębiorstwach, Ekonomiczne Problemy Usług 116, 363-373.

BYGRAVE W.D., HUNT S.A., 2005: Global Entrepreneurship Monitor 2004. Financing Report, Babson College and London Business School, Babson Park.

CARTER S., SHAW E., LAM W., WILSON F., 2007: Gender, Entrepreneurship, and Bank Lending: The Criteria and Processes Used by Bank Loan Officers in Assessing Applications, Entrepreneurship Theory and Practice 31 (3) 427-444.

CHAKRAVARTY S., XIANG M., 2009: What Discourages Small Businesses from Asking for Loans? The International Evidence on Borrower Discouragement, Working Papers 903, Purdue University, West Lafayette.

FREEL M., CARTER S., TAGG S., MASSON C., 2012: The Latent Demand for Bank Debt: Characterizing "Discouraged Borrowers", Small Business Economics 38, 399-418.

HAKAŁO G., RATAJCZAK D., 2014: Etapy i koszty procesu sukcesji oraz możliwości ich finansowania, Ekonomiczne Problemy Usług 111, 346-357.

KATA R., 2013: Czynniki behawioralne determinujace korzystanie przez rolników z kredytów inwestycyjnych, Zeszyty Naukowe Szkoły Głównej Gospodarstwa Wiejskiego. Ekonomika i Organizacja Gospodarki Żywnościowej 103, 53-65.

KATA R., WALENIA A., 2015: Financial exclusion Farmers and Entrepreneurs, Journal of Agribusiness and Rural Development 2 (36), 225-235.

LUCEY B., SANCHEZ-VIDAL J., McANBHAIRD C., GURDGIEV C., 2012: What Determines the Decision to Apply for Credit? Evidence for Eurozone SMEs, Institute for International Integration Studies Discussion Paper 145, Dublin.

MATEJUN M., SZYMAŃSKA K., 2012: Finansowanie $i$ wspomaganie rozwoju firm sektora MSP, [w:] M. Matejun (red.), Zarzadzanie mała i średnia firma w teorii $i$ w ćwiczeniach, Difin, Warszawa. 
ORECHWA-MALISZEWSKA E., KOPCZYKA., 2003: Finansowe aspekty funkcjonowania matych i średnich przedsiębiorstw, Wydawnictwo WSFiZ w Białymstoku, Białystok.

PARP, 2015: Raport o stanie sektora matych $i$ średnich przedsiębiorstw $w$ Polsce $w$ latach 2013-2014, Warszawa.

PeKaO SA, 2014: Raport o sytuacji mikro i matych firm w roku 2013, Warszawa.

SADOWSKA M., 2014: Źródła finansowania inwestycji sektora matych i średnich przedsiębiorstw $w$ Polsce, Ekonomiczne Problemy Usług 111, 346-357.

SAWICKA A., TYMOCZKO I.D., 2014: Dlaczego polskie przedsiębiorstwa nie korzystaja z kredytu? Zjawisko zniechęconego kredyto(nie)biorcy, Materiały i Studia NBP 310.

SKOWRONEK-MIELCZAREK A., 2002: Zewnętrzne źródła finansowania matych i średnich przedsiębiorstw $w$ Polsce, Monografie i Opracowania SGH 499.

SMALLBONE D., RAM M., DEAKINS D., ALDOCK R.B., 2003: Access to Finance by Ethnic Minority Businesses in the UK, The International Small Business Journal 21 (3).

\section{Abstrakt}

W opracowaniu dokonano oceny skali, w jakiej małe i średnie przedsiębiorstwa w Polsce wykorzystują kredyty bankowe w finansowaniu działalności gospodarczej. Ponadto określono bariery i ograniczenia w dostępie MSP do tego źródła finansowania. Dokonano klasyfikacji i oceny znaczenia poszczególnych ograniczeń przez pryzmat przyczyn pasywności kredytowej MSP oraz ich wykluczenia kredytowego.

Słowa kluczowe: małe i średnie przedsiębiorstwa, kredyty bankowe, finansowanie działalności gospodarczej

\section{Using the bank credits by small and medium enterprises in Poland}

\section{Abstract}

The study encompasses the assessment of which scale small and medium enterprises in Poland use bank credits to finance business. Moreover, the barriers and constraints of SMEs in the access to such financing source have been defined. The classification and assessment of the significance of particular constraints have been performed by means of the reasons for credit passiveness of SMEs and their credit exclusion. 